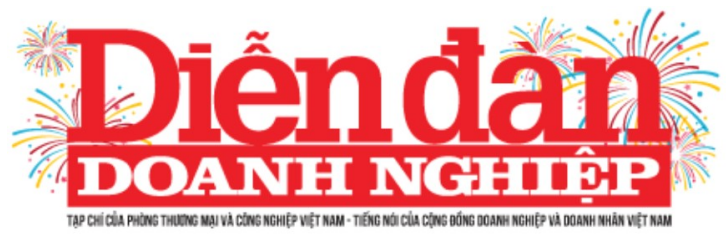

20/12/2008 | 00:00 GMT+7

In bài viết $(\underline{\mathrm{Ctrl}+\mathrm{P}})$

\section{Cội nguồn của văn minh kinh doanh trong tâm thức người Việt}

\section{I"Văn minh làm giàu và nguồn gốc của cảil" của tiến sĩ Vương Quân Hoàng là một trong số ít những cuốn sách viết về kinh tế ở Việt Nam đã đụng đến gốc rễ của một vấn đề mà đôi khi chúng ta đã lãng quên, đó là nguồn gốc của cải, của những xã hội, những nền văn hóa tự thân vận động hoặc trao đổi, giao lưu với nhau bằng kinh tế.}

"Văn minh làm giàu và nguồn gốc của cải" của tiến sĩ Vương Quân Hoàng* là một trong số ít những cuốn sách viết về kinh tế ở Việt Nam đã đụng đến gốc rễ, đến tận cùng của một vấn đề tưởng như quá đỗi quen thuộc mà đôi khi chúng ta đã lãng quên, đó là nguồn gốc của cải, của những xã hội, những nền văn hóa tự thân vận động hoặc trao đổi, giao lưu với nhau bằng kinh tế. Dễ thấy, một thái độ làm việc nghiêm túc, tích cóp tri thức, một bộ óc tư duy linh hoạt, sự nghiền ngẫm, suy tư của tác giả về văn minh kinh doanh, về tiền tệ, về nguồn gốc của cải, sự vận động không ngừng của nhân loại trong quá trình giao thương với nhau. Đầy ắp trong cuốn sách là những kinh nghiệm thực tiễn, tri thức phong phú, sự am hiểu sâu sắc trên mọi lĩnh vực từ văn hóa, tư tưởng, triết học cho đến hội họa, kinh tế, lịch sử Việt Nam, lịch sử các nước... Được đi nhiều nơi, tiếp cận nhiều nền văn hóa, được gặp gỡ nhiều người đã cho Vương Quân Hoàng một cái nhìn khá toàn diện về thế giới, hay như cách nói của người phương Đông,

Vương Quân Hoàng có một nhân sinh quan, một thế giới quan khá phong phú.Đọc sách, người đọc nhận thấy ở Vương Quân Hoàng là sự mâu thuẫn của một triết gia, là óc hoài nghi của một nhà khoa học, và một nền tảng văn hóa vững chắc vùng một sự góp nhặt của hai nền văn hóa Đông - Tây. Mặc dù cho rằng văn hóa Khổng giáo bao trùm lên xã hội, làm trì trệ, đẩy lùi văn minh không chỉ của Trung Hoa mà còn toàn bộ những nước mà nó ảnh hưởng (trong đó có Việt Nam) nhưng cũng chính ở khúc quanh này ta lại bắt gặp một người mê say văn hóa, tư tưởng của Khổng giáo, người đào sâu tư tưởng Khổng giáo đến như vậy. Rõ ràng ở sự chiêm nghiệm của Vương Quân Hoàng có sự đan xen giữa suy tư 


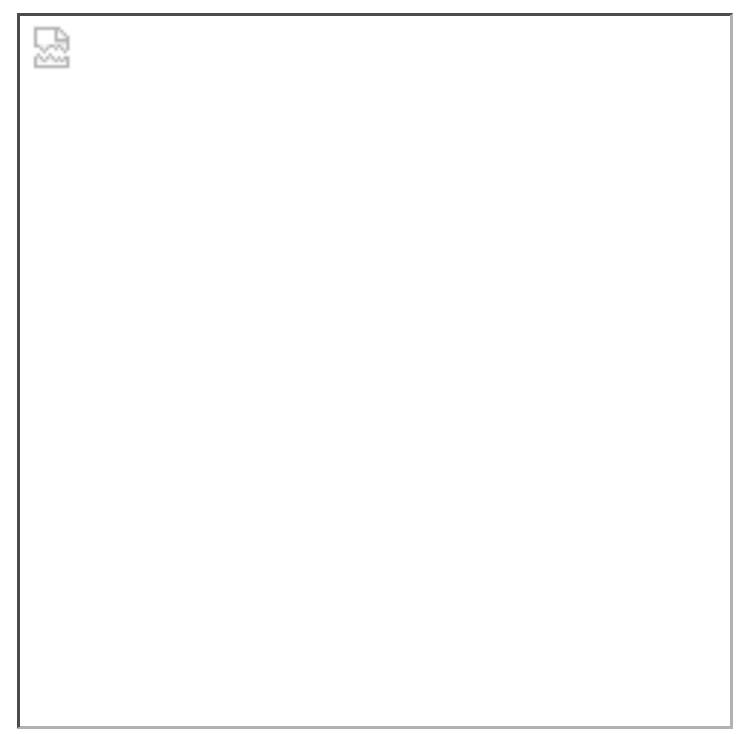

văn hóa phương Đông và trạng thái tìm tòi, phát kiến của văn minh phương Tây (cần lưu ý một cách cảm quan rằng những nhận thức toàn diện của anh được hoàn thiện trong môi trường học vấn phương Tây). Văn minh phương Tây cho anh một quan niệm nhìn nhận vấn đề rõ ràng, mạch lạc, và quan trọng là giản dị, bởi sự đơn giản đã là kết tinh của đỉnh cao, nó cũng đồng thời bồi đắp cho anh tinh thần thực nghiệm (theo cách viết của anh là người phương Tây ưa tìm ra chân lý) nhưng ở đâu đó ta lại thấy Vương Quân Hoàng không hề có thái độ khước từ văn hóa phương Đông.Một trong những điểm thú vị khác mà người đọc cảm thấy hứng khởi chính là óc hoài nghi của tác giả khi đưa ra nhận định: Nhật Bản là phương Tây, dễ thấy nó sẽ vấp lại phản ứng mạnh mẽ từ các học giả, các nhà kinh tế phương Tây cho rằng, nền kinh tế Nhật Bản không vận hành theo logic kinh tế phương Tây, hay kinh tế Nhật không cùng hệ thống với kinh tế phương Tây. Ở mức độ nào đó va chạm với ý kiến của nguyên thủ tướng Nhật Hosokawa Morihiro rằng, Nhật Bản không có ý định xây dựng "bản sắc" để trở thành thành viên phương Tây. Tuy nhiên, điều quan trọng cần nhận thức ở đây là người Nhật đã hiện đại hóa hay phương Tây hóa? Cũng tương tự như vậy, ở một vấn đề khác là liệu văn minh của các nước trong vùng ảnh hưởng của tư tưởng Khổng giáo có bị ảnh hưởng không và ảnh hưởng ở mức độ nào. Một trong vô vàn những lý do khiến cho giới kinh doanh của Việt Nam chưa bằng với nhiều quốc gia trên thế giới đó chính là cái tâm thức Nho giáo ăn sâu trong gốc rẽ chúng ta khiến chúng ta vẫn chưa có sự coi trọng đúng mức với vai trò của thương nhân. Nếu ai đó dẫn ra rằng, cũng là ảnh hưởng của Nho giáo, tại sao Singapore, Nhật Bản, Hàn Quốc lại phát triển rực rỡ đến vậy? Rằng, sao yếu tố bản địa hóa thế hệ thứ 2 , thứ 3 ở Singapore lại thành công nếu không phải họ xác định rằng Khổng giáo chính là nền tảng cho thành công của họ? Còn với Nhật Bản, nếu không phải là sự xác định nền tảng Nho giáo thì họ cũng giao thoa với nền văn hóa Trung Hoa ở bộ chữ tượng hình. Nhưng vấn đề ở đây là tại sao các nước khác trong khu vực như, Thái Lan, Indonesia, Philippines lại phát triển tốt hơn Việt Nam. Còn rất nhiều thú vị khác chờ bạn đọc khám phá để rồi khi gấp sách lại bạn có thể mỉm cười ý vị.

TS Vương Quân Hoàng - nghiên cứu viên cấp cao của Trung tâm Emile Bernheim, Đại học Tổng hợp Bruxelles, Bỉ; Đồng sáng lập hệ thống phân tích và truyền thông kinh doanh www.saga.vn. Ông cũng là tác giả của một số đầu sách nổi tiếng như "Văn minh làm giàu \& nguồn gốc của cải", "Nguyên tắc tài chính toán trong thị trường chứng khoán" 


\section{Tài liệu tham khảo:}

[1] Vương Quân Hoàng. (2007). Văn minh làm giàu \& nguồn gốc của cải. Nxb Chính trị quốc gia, Hà Nội.

[2] Vương Quân Hoàng, Ngô Phương Chí. (2000). Nguyên lý tài chính-toán của thị trường chứng khoán. Nxb Chính trị quốc gia, Hà Nội. 